\title{
Effect of different Mulching Materials on the Yield of Quality Protein Maize in Danbatta Local Government Area, Kano State Nigeria
}

\author{
Sanda, Ahmad. Rabo ${ }^{1 *}$, Shehu, Abdul Jalal. Dattijo. ${ }^{2}$, Danladi Ado ${ }^{3}$, Calvin Alvin Gaye ${ }^{4}$ \\ ${ }^{* 1,4}$ Department of Graduate School. University of the Philippines Los Banos, 4031 Laguna. \\ ${ }^{2,3}$ Department of Agriculture, Audu Bako College of Agriculture Danbatta, Kano State
}

\begin{abstract}
Field research was conducted on the effects of different mulching materials on the yield of Quantity protein maize which include polythene sheet, dry grasses and control. The different mulching materials were tested on nine (9) ridges each measuring $10 \mathrm{~m}$. The research was laid out in a completely randomized block design each treatment replicated three times. The parameters measured include weight of cobs, weight of 100grain, and total grain, there was no statistical difference in the weight cobs among all the treatments, similarly, there was also no statistical different in the weight of 100 grain. As far the weight of grain per $5 \mathrm{~m}^{2}$ there was a significant difference among the treatments with polythene sheet covered plots that have $0.25 \mathrm{~kg}$, however, the grass-mulched plots $0.16 \mathrm{~kg}$ was statistically similar to the control plots $0.15 \mathrm{~kg}$. And finally for store weight observed per $5 \mathrm{~m}^{2}$, polythene sheet covered plots were significantly higher than grass-mulched plots which are also significantly different to control plots with the values of $1.23 \mathrm{~kg}, 1.21 \mathrm{~kg}$ and $0.71 \mathrm{~kg}$ respectively.
\end{abstract}

Keywords-Mulch, grain, store, cob, polythene.

\section{INTRODUCTION}

Given the importance of maize in the Nigeria economy, one would have expected that the nation would be self-sufficient in the production of the crop. Considering the fact that the crop can be grown in most parts of the country (Ogunbiled and Olokosi, 1990), but one will wonder why the country is not self-sufficient in maize production. Problems cited as constraining the production of maize in Nigeria are stagnant production technology among Nigeria's farming community majority of whom are the small scale producers and water resource management (Ahmed and Kura, 2007). To enhance crop production mulch, or a production cover applied to the soil surface so as to minimize water losses due to evaporation and enhanced water use efficiency was suggested by Ahmad and Kura, 2007 when they showed that application of straw mulch significantly affect the performance of maize as yield of mulched plots significantly and positively increase the yield. Reporting an different Crop, Ramadan and Nwokocha, (2000), Sanda and Ogunwole (2006), shows that application of straw mulch resulted in yield increase of 5.2t/ha over that obtained from un mulch tomato plot and marketable fruit yield of the crop also increase significantly. Therefore this paper is aimed at studying the influence of mulch application on the yield of maize at Audu Bako College of Agriculture, Danbatta, Kano State, Nigeria.

Lobell and Burke (2010) suggested that an increase in temperature of $2^{\circ} \mathrm{C}$ would result in a greater reduction in maize yields within sub-Saharan Africa than a decrease in precipitation by $20 \%$. A recent analysis of more than 20,000 historical maize trial yields in Africa over a period of eight years combined with weather data showed that for every degree day above $30^{\circ} \mathrm{C}$ grain yield was reduced by $1.0 \%$ and $1.7 \%$ under optimal rainfed and drought conditions, respectively (Lobell et al., 2011b).

Dry season and in some cases wet season maize (Zea mays L.) is one of the most popular grain crops in the semiarid, but low air temperature and drought in April May often result in poor plant establishment. Recently, a method using double ridges and furrows mulched with plastic film for micro-catchment water harvesting has been considered a great technical innovation in dryland farming systems for wide use in spring maize (Gao et al., 2008). This technique has now been widely applied to maize in semiarid areas, and has completely replaced conventional tillage management owing to its significant effect on water harvesting and increased yields (Zhang et al., 2006; Ma et al., 2008).

\section{MATERIALS AND METHODS}

The trail was conducted at teaching and Research Farm of Audu Bako College of Agriculture, Danbatta, Kano State.

The climate of the area is characterized by an alternative hot rainy season and cool, dry season with the mean annual rainfall of $46 \mathrm{~mm}$, a mean annual temperature of $37^{\circ} \mathrm{C}$ located at latitude $1155, \mathrm{~N}, 8^{0} 20$, E (Areola, 2000). The soil has been characterized as sandy loam (Sanda 2005). 
Two different mulching materials (polythene sheet, and grass) and a control (no mulch plots) were used as the experimental treatments and were replicated three times and they were laid out in a completely randomized block design an improved Quantity Protein Maize (QPM) variety source from Kano Agricultural and Rural Development Authority (KNARD) was used as a test crop. All agronomic practices involved in maize cultivation from land clearing to harvest were followed at the end of experiment the following observation were recorded; weight of store, weight of cobs, weight of 100 grains and total grain weight. The data generated were subjected to analysis of variance using a gen stat package. Treatments with significant difference were compared and separated using least significant difference (LSD) and $0.05 \%$ level of probability.

\section{RESULT AND DISCUSSIONS}

\subsection{Effects of different Mulching Materials on the Store Weight And Cobs Weight of Maize at Danbatta:-}

The weight of store a significant difference among all the treatments, with polythene sheet treatment having the highest cobs weight of $1.23 \mathrm{~kg}$, followed by the grass mulch with a value of $1.22 \mathrm{~kg}$, which are statistically different with control plot with a value of $0.71 \mathrm{~kg}$. This indicates that polythene covered plots were warmed and allows little or no moisture to evaporate from the soil surface and hence more moisture is avail for the crop metabolic activities which positively affect the crop performance, similar observation was made by Ahmad 2009, W. Mupangwa et al., 2016, Xu J, et al., 2015. However, there was no statistical different in the weight of cobs among all the treatments tested.

However, the effects of the different treatments (polythene sheet, grass and control mulch) that were evaluated on the cob weight were found to have no significant different among the various treatments. The grass, polythene treatments and the untreated treatment were found to be similar, even though control gave a little value of cob weight compared to others, whichever is adopted by the farmers could be as beneficial, but control can then be more economical in terms of cob weight, though it will not be the ultimate aim of maize production, but may be regarded as one of the components that determine maize yield.

\subsection{Effect of different Mulching Materials on the weight of 100 grains and total Grain Yield of Quality protein maize at Danbatta}

Grass-mulched plots shows a statistical different away the treatments with a value of $0.04 \mathrm{~kg}$ as against the polythene sheet and control plots with a values of $0.01 \mathrm{~kg}$ and $0.01 \mathrm{~kg}$ respectively as far as 100 grain weight is concern as shows in Table 2 .

However, the weight of area grains from the quadrant $5 \mathrm{~m}^{2}$ shows that there was a significant different between polythene sheet covered plots with grass-mulched and control plots, polythene sheet covered plots has $0.25 \mathrm{~kg}$ and grass-mulched and control plot has $0.16 \mathrm{~kg}$, and $0.15 \mathrm{~kg}$ respectively which are statistically similar. This however, shows that polythene covered plots were superior interns of weight of area grains from the quadrant of $5 \mathrm{~m}^{2}$.

\section{TABLE 1}

EFFECT OF DIFFERENT MULCHING MATERIALS ON THE STORE WEIGHT AND COBS WEIGHT OF QPM AT DANBATTA

\begin{tabular}{|c|c|c|}
\hline Treatments & Store weight $(\mathbf{k g})$ & Cobs weight $(\mathbf{k g})$ \\
\hline Polythene covered sheet plots & $1.23 \mathrm{~b}$ & 0.12 \\
\hline Grass mulched plots & $1.21 \mathrm{a}$ & 0.12 \\
\hline Control plots & $0.71 \mathrm{a}$ & 0.13 \\
\hline LSD & 0.20 & \\
\hline
\end{tabular}

\section{TABLE 2}

EFFECT OF DIFFERENT MULCHING MATERIALS ON WEIGHT OF 100 GRAIN AT TOTAL GRAIN WEIGHT OF QPM AT DANBATTA

\begin{tabular}{|c|c|c|}
\hline Treatments & Weight of 100 grain (kg) & Total grain weight (kg) \\
\hline Polythene covered sheet plots & 0.01 & $0.25 \mathrm{~b}$ \\
\hline Grass mulched plots & 0.04 & $0.16 \mathrm{a}$ \\
\hline Control plots & 0.01 & $0.15 \mathrm{a}$ \\
\hline LSD & - & 0.04 \\
\hline
\end{tabular}

Considering the results presented above on the weight of 100 grain, both polythene and control have the value that is lower than that obtained under Grass-mulched plots which may be attributed to the fact that towards the grain filling/ milking stage 
of the maize the grasses used for mulching started to decomposed and hence releases some nutrients that may be uptake by the maize and hence improves it performance above other treatments that does not have a decomposable organic residue, similar observations was made by Ahmad and Nasiru 2009 at the same location.

The effect of the treatments on the total grain weight as shown in Table 2, indicates that polythene covered treatment is superior to other treatments, and the probable reasons could be due to the continuous moisture retention of this treatment all through the experimental period, which signified the important of water availability to maize crop at all level of critical growth stages, this was also suggested by Yin, et al., 2016, Ahmad and Nasiru, 2009. Although Grass mulched and Control were statistically similar, but Grass mulched plots shows some element of superiority over Control for the total grain yield and it might be as well due to the higher available moisture between the two respective plots.

\section{CONCLUSION}

In an area with erotic and unstable rainfall maize production can be enhance by the application of mulch especially polythene sheet mulch which a part from minimizing evaporation losses can also help to improve water use efficiently of the crop and if not available, dried grasses can be use as a mulching materials which has an added advantage of when decompose increase the organic matter content of the soil. Economically it is also wise to use polythene sheet as a mulching materials, because the yield difference as observed in this study can justify the cost of buying the polythene materials and when properly taken care of, it can be used for two or more season, but in a situation whereby polythene materials may be found too expensive or may not be available, the use of dried grasses could be an alternative, which could have an added advantage of when decomposes increases the organic carbon content of the soil.

\section{REFERENCES}

[1] Ahmad, R.S. (2009) Effect of plastic mulch an germination counts at early growth of Rice (Oryza sativa) at Kaduna, Kano River Irrigation Project, Nigeria Proceedings of the $1^{\text {st }}$ National Annual Conference of Niger State College of Agriculture, Mokwa, Niger State, Nigeria. November 3-6, 2009. PP. 92-99.

[2] Ahmad, R.S. and Kura, H.N. (2009) Performance of Maize as influence by Irrigation scheduling and Mulched at Thomas Irrigation Project Danbatta, Kano Proceeding of the $13^{\text {th }}$ National Irrigation and Drainage seminar, Gidan Matasa Cultural Centre Minna, Niger State 11-14 June, 2007. PP. 63-65

[3] Areola, Olusegun (2000) Certificate physical and Human Geography for Senior Secondary Schools, Gohchenleon, Reprinted 2000 University Press Ibadan. Pp. 214-215.

[4] Gao, Y.Q., Zhang, G.P., Chen, Z.G., Yan, P., 2008. The innovation of new agriculture technique for drying farming system. Fazhan. Yuedujujiao. 10, 5-6 (in Chinese)

[5] Lobell, D. B., and Burke, M. B. 2010. Agric. Forest Metero. 150, 1443-1452.

[6] Lobell, D. B., Bänziger, M., Magorokosho, C., and Vivek, B. 2011b. Nature-Climate Change, DOI:10.1038/ NCLIMATE1043, 1-4.

[7] Ma, S.Z., Wang, S.J., Chen, J.J., Su, M., Li, X.S., 2008. Effects of c film mulch modes on maize production, soil temperature and moisture in dryland. Gansu Agric. Sci. Technol. 6, 20-23 (in Chinese)

[8] Ramadan, A.R., and Nwokeocha, C.U. (2000) Effects of furrow Irrigation methods, mulching and soil water suction on the growth and yield and water use efficiency of tomato in the Nigerian Savannah Agricultural water management 45:317-330

[9] Sanda, A.R. (2005) Chemical Properties of ABCOA Irrigated plot. Thomas Irrigation Project. Bulletin, Vol.19, No 1, 2006

[10] Sanda, A.R. and Ogunwole, J.O. (2006) Effect of drainage water re-cycled and Mulch on the growth at yield of tomato at Kaduna Irrigation Project. $24^{\text {th }}$ Annual Conference of Horticultural Society of Nigeria, Gombe State University, Gombe $17^{\text {th }}-22^{\text {nd }}$ September, 2006.

[11] W. Mupangwa, I. Nyagwambo and E. Mutsambu (2016). Effect of different mulching materials on maize growth and yield in conservation agriculture systems of sub-humid Zimbabwe. AIMS Agriculture and Food, 1(2): 239-253.

[12] Xu J, Li C, Liu H, Zhou P, Tao Z, Wang P, et al. (2015) The Effects of Plastic Film Mulching on Maize Growth and Water Use in Dry and Rainy Years in Northeast China. PLoS ONE 10(5): e0125781. doi:10.1371/journal.pone.0125781

[13] Yin, X., J.E. Olesen, M. Wang, K.-C. Kersebaum, H. Chen, S. Baby, I. Öztürk, F. Chen. 2016. Adapting maize production to drought in the Northeast Farming Region of China. European Journal of Agronomy. 77: 47-58.

[14] Zhang, L., Niu, J.B., Zhao, F., 2006. Film mulch modes for increasing rainfall use efficiency of dryland corn. Agric. Res. Arid Areas 24 (2), 8-17 (in Chinese with English abstract). 